Poster Section

\title{
The activity of enzymes can be modified by homeopathic dilutions of their effectors
}

\author{
Elzbieta Malarczyk \\ M. Curie-Sklodowska Univ., Lublin, Poland
}

\begin{abstract}
Introduction: The fungal and bacterial materials are very useful for testing the influence of low and very low doses of low molecular phenolic effectors on enzymatic system of phenoloxidases when they are incubated together in the reaction space.
\end{abstract}

Aim: Searching for the model useful biological systems to study the action of diluted low molecular substances on living organisms, which is based on common physical and biochemical analytical procedures.

Methods: The fungal and actinomycetal bacterial materials from laboratory cultures as a source of common phenoloxidases, laccase, peroxidase and O-demethylase as well as the pure plant peroxidase were used in experiments described earlier [1-5]. Subsequent dilutions of low molecular phenolic metabolites, appropriate for studied enzymatic systems, prepared in $75 \%$ ethanol in the proportion of 1:100 (centesimal) and dynamized by shaking in accordance with homeopathic procedures were prepared in our laboratory. During experiments with bacterial and fungal materials and a pure plant peroxidase, which were incubated together with subsequent dilutions of proper phenolic effector, different analytic methods were used including a gel (PAGE) [4] and capillary (MEKCE) electrophoresis [5], spectral and colorimetric methods [1,2,3] as well as the electron microscopy [5].

Results: In the light of presented data [1-5], the incubation of biological material with diluted phenolic effectors induces various effects on tested enzyme activity. It changed in sinusoidal manner with a gradual growth of dilution rate of tested effectors, which was distinctly visible on the diagram when the number of dilutions was localized on abscissa and biological activity on the ordinate.

Exemplary results of the chosen experiments will be presented. For tested enzymes: laccase, peroxidase and O-demethylase, the distance between maximal points of enzymatic activity, shown on a sine curve, repeats more often every 10 subsequent centesimal dilutions. Along with the extension of incubation period the displacement of maximal and minimal points on curve were noticed, which revealed a dynamic aspect of studied phenomenon.

Conclusions: Fungal and bacterial cells seem to be a very convenient material for studying the action of diluted metabolites on enzymatic systems because their popular presence in environment. Results of all experiments confirmed the same nature of the mentioned observations. Because other authors had similar conclusion concerning human [6,7] and plant materials [8,9], the described relations seem to be common in natural world. It could also be stressed that the therapeutic effect of homeopathic remedies could be based on the mechanism described above and it is highly probable that it leads to a normalisation of disturbed enzyme systems in the living organisms.

Keywords: enzymes, effectors, biological activity 


\section{References:}

[1] Malarczyk E et al. Effect of Low Doses of Guaiacol and Ethanol on Enzymatic Activity of Fungal Cultures. Nonlinearity Biol Toxicol Med 2003, 1:167-178. PubMed Central Full Text.

[2] Malarczyk E et al. Effect of Low and Very Low Doses of Simple Phenolics on Plant Peroxidase Activity. Nonlinearity Biol Toxicol Med 2004, 2:129-141. PubMed Central Full Text

[3] Malarczyk E. Kinetic changes in the activity of HR-peroxidase induced by very low doses of phenol. Int J High Dilution Res [online]. 2008 [cited 2012 Apr 24]; 7(23): 48-55. Available from: http://www.feg.unesp.br/ ojs/index.php/ijhdr/article/view/37/349

[4] Malarczyk E, et al. Influence of very low doses of mediators on fungal laccase activity - nonlinearity beyond imagination. Nonlinear Biomed Phys 2009, 3:10. PubMed Central Full Text

[5] Malarczyk E, et al. Nonlinear changes in the activity of the oxygen-dependent demethylase system in Rhodococcus erythropolis cells in the presence of low and very low doses of formaldehyde. Nonlinear Biomed Phys. 2011, 5:9. Open access.

[6] Belon P (Ed). Activite de dilutions d'histamine sur la degranulation des basophiles. In: Recherche en homeopathie 4th ed. Lyon, Editions Boiron: 2006, 48-55.

[7] Szende, B., Tyihák, E., Király-Véghely, Zs. Dose-dependent effect of resveratrol on proliferation and apoptosis in endothelial and tumor cell cultures. Exp. Mol. Med . 2000, 32: 88-92.

[8] Manninger K, Csösz M, Tyihak E. Induction of resistance of wheat plants to pathogens by pretreatment with N-methylated substances. Acta Biol Hungar 1998, 49:275-280.

[9] Tyihák E, Király-Véghely Z: Interaction of trans-resveratrol with endogenous formaldehyde as one basis of

\section{(c)) EY-NC-ND Licensed to GIRI}

Support: authors declare that this study received no funding

Conflict of interest: authors declare there is no conflict of interest

Received: 01 June 2012; Revised: 10 August 2012; Published: 30 September 2012.

Correspondence author: Elzbieta Malarczyk, ela.malarczyk@gmail.com

How to cite this article: Malarczyk E. The activity of enzymes can be modified by homeopathic dilutions of their effectors. Int J High Dilution Res [online]. 2012 [cited YYYY Month dd]; 11(40):185-186. Proceedings of the XXVI GIRI Symposium; 2012 Sep 20-22; Florence (Italy). GIRI; http://www.feg.unesp.br/ ojs/index.php/ijhdr/article/view/565/599 